\author{
Slawomir Kurek, Tomasz Rachwal, Mariusz Szubert \\ Uniwersytet Pedagogiczny \\ im. Komisji Edukacji Narodowej \\ w Krakowie
}

\title{
Kształtowanie kompetencji biznesowych uczniów gimnazjum w świetle opinii nauczycieli na podstawie wyników badań prowadzonych w ramach europejskiego projektu FIFOBI
}

W opinii pracodawców oraz specjalistów od europejskiego rynku pracy, absolwenci szkół nie są dostatecznie wyposażeni w wiedzę i umiejętności związane z funkcjonowaniem w świecie biznesu, czyli w tzw. kompetencje biznesowe. W szerokim ujęciu na kompetencje te składają się kompetencje w zakresie wyposażenia w wiedzę ekonomiczną, kompetencje społeczne oraz kompetencje osobiste nawiązujące do postawy przedsiębiorczości. W ujęciu zawężonym są to kompetencje bezpośrednio związane z przygotowaniem do prowadzenia działalności gospodarczej (Kurek, Rachwał 2010a). Na dużą rolę kompetencji biznesowych, zarówno w rozwoju społeczno-gospodarczym układów przestrzennym różnej skali, jak i rozwoju sektora małych i średnich przedsiębiorstw, w tym firm rodzinnych oraz życiu zawodowym każdego człowieka, zwraca uwagę wielu autorów (m.in. Kurek, Rachwał 2010, 2011; Naudé 2008; Osuch 2011; Rachwał 2010; Wach 2007; Zioło 2006, 2007, 2010, 2011). Problematyka kształtowania kompetencji biznesowych uczniów w ramach obowiązkowej edukacji w państwach członkowskich Unii Europejskiej wydaje się więc być istotnym zagadnieniem badawczym.

Kształcenie kompetencji biznesowych w państwach UE jest bardzo zróżnicowane. Główną tego przyczyną są odmienne systemy edukacyjne (Kurek, Rachwał 2010). Przykładowo w Polsce obowiązkowa edukacja kończy się w praktyce na poziomie gimnazjalnym, podczas gdy w innych krajach na etapie ponadgimnazjalnym, przy czym konsekwentnie przestrzega się obowiązku uczęszczania do szkoły aż do osiągnięcia pełnoletniości. W efekcie kształcenie kompetencji biznesowych rozpoczyna się i kończy na różnych poziomach obowiązkowej edukacji. Ponadto kompetencje biznesowe kształtowane są w obrębie różnych przedmiotów, niekoniecznie dedykowanych specjalnie edukacji ekonomicznej. W Polsce w ramach obowiązkowej edukacji kompetencje biznesowe w szerokim i wąskim rozumieniu kształci się głównie na lekcjach wiedzy o społeczeństwie. Treści związane z kształceniem w zakresie kompetencji społecznych i osobistych znajdują się także w podstawach programowych wielu innych przedmiotów, w tym języka polskiego, historii, geografii, przysposobienia do życia w rodzinie (Borowiec, Rachwał 2011; Kurek, Rachwał 2010). Podobna sytuacja ma miejsce w wielu krajach Unii Europejskiej (Kurek, Rachwał 2010).

\section{Cele i metoda badawcza}

Celem realizowanego w latach 2009-2011 projektu badawczego FIFOBI - „Fit for business: developing business competencies in school” (,Zdolni do biznesu: kształtowanie kompetencji 
biznesowych uczniów”) było zbudowanie w ramach obowiązku szkolnego innowacyjnego modelu kształcenia biznesowego, który mógłby stanowić bazę dla budowy strategii kształcenia przez całe życie i kształcenia na wyższych etapach edukacji. Szczegółowe założenia projektu FIFOBI przedstawili S. Berger i M. Pilz (2010) oraz S. Kurek i T. Rachwał (2010). Projekt dotyczył siedmiu krajów: Niemiec, Polski, Austrii, Łotwy, Portugalii, Węgier i Wielkiej Brytanii. W pierwszym etapie jego realizacji zbadano zapisy w podstawach programowych i programach nauczania dotyczące kształtowania kompetencji biznesowych i przygotowania do zawodu (kształcenia przedzawodowego) w dwóch ostatnich latach obowiązkowej edukacji.

Niniejsza praca przedstawia efekty badań przeprowadzonych w drugim etapie realizacji projektu. Celem tych badań było zidentyfikowanie mocnych i słabych stron systemu edukacji w zakresie kształtowania kompetencji biznesowych uczniów gimnazjów na podstawie opinii nauczycieli - osób kluczowych w systemie edukacji. Badania przeprowadzono metodą wywiadu z nauczycielami przedmiotu wiedza o społeczeństwie z sześciu gimnazjów. Odbyły się one w szczególnej sytuacji, związanej z wdrażaniem od 2009 roku nowej podstawy programowej przedmiotu wiedza o społeczeństwie i nowych programów nauczania tego przedmiotu.

Nauczycielom zadano kilkadziesiąt pytań dotyczących: podstawy programowej kształcenia w zakresie wiedzy o społeczeństwie oraz realizacji wybranego przez nich programu nauczania odniesieniu do kształtowania kompetencji biznesowych; rankingu czterech kompetencji składających się na kompetencje biznesowe w szerokim rozumieniu w procesie nauczania przedmiotu wiedza o społeczeństwie; propozycji zmian w podstawie programowej (programach nauczania) w zakresie kształcenia biznesowego, wynikających z realizacji wybranych przez nich programów nauczania; metod nauczania; edukacji przedzawodowej; oceny procesu i efektów kształcenia w przekroju wszystkich kompetencji.

\section{Charakterystyka otoczenia badanych szkół}

Wytypowane szkoły znajdują się w województwach: małopolskim, łódzkim i kujawsko-pomorskim. Przy ich wyborze zastosowano następujące kryteria:

- położenie administracyjne miejscowości (województwo, powiat), status miejscowości (miasto, wieś), liczba mieszkańców (miasto duże, średnie lub małe), odległość wsi od miasta,

- funkcje administracyjne miejscowości (miasto wojewódzkie lub powiatowe, wieś gminna lub sołecka),

- funkcje gospodarcze regionu (region przemysłowy, rolniczy lub o dominującej funkcji usługowej),

- poziom rozwoju gospodarczego regionu oceniany na podstawie między innymi stopy bezrobocia w 2009 roku.

Wywiady przeprowadzono w:

- prywatnym gimnazjum w Krakowie,

- publicznym gimnazjum w Krakowie,

- publicznym gimnazjum w powiecie wielickim (woj. małopolskie),

- publicznym gimnazjum w Wieluniu (woj. łódzkie),

- publicznym gimnazjum w powiecie wieluńskim (woj. łódzkie),

- publicznym gimnazjum w powiecie lipnowskim (woj. kujawsko-pomorskie).

Pięć gimnazjów to szkoły publiczne, jedno - placówka prywatna. Badane szkoły funkcjonują w zróżnicowanych środowiskach społecznych i gospodarczych. Dwie z nich znajdują się w Krakowie, mieście wojewódzkim, jednym z największych w Polsce, drugim pod względem liczby mieszkańców (ok. 755 tys.). W Krakowie dobrze prosperuje gospodarka, co odzwierciedla między innyminiska stopa bezrobocia (3,4\%). Bardzo dobrze rozwinięte są usługi, szczególnie turystyczne 
i edukacyjne. Miasto to należy do najważniejszych ośrodków nauki, kultury i sztuki w Polsce o wielowiekowej tradycji, dzięki czemu stwarza młodzieży znakomite warunki rozwoju intelektualnego oraz zawodowego. Kraków jest też kluczowym ośrodkiem przemysłowym, w którym obok tradycyjnych działów produkcji rozwija się przemysł zaawansowanej technologii wymagający pracowników o odpowiednich kwalifikacjach (Rachwał 2006) oraz nowoczesne usługi dla biznesu (Micek 2008; Micek, Działek, Górecki 2011), w tym informatyczne, finansowo-księgowe oraz w zakresie prac badawczo-rozwojowych. Obie badane krakowskie szkoły zlokalizowane są w dzielnicach, w których dominuje działalność usługowa.

Jedna $\mathrm{z}$ badanych szkół znajduje się w małym mieście Wieluniu (25 tys. mieszkańców), w województwie łódzkim. Na tle innych małych i średnich miast województwa łódzkiego Wieluń ma dobrze rozwinięte usługi i przemysł. Rynek usług ma przede wszystkim zasięg lokalny (powiat) i ogólnokrajowy w odniesieniu do przetwórstwa przemysłowego (produkcja artykułów spożywczych, środków transportu, konstrukcji stalowych, artykułów chemicznych i z tworzyw sztucznych). Gospodarka miasta znajduje się na średnim poziomie rozwoju, stopa bezrobocia wynosi około $11 \%$. W mieście i jego najbliższej okolicy nie ma przemysłu wymagającego pracowników o wysokich kwalifikacjach lub innych niż tradycyjnych zawodów. Na rynku edukacji ponadgimnazjalnej dominują licea ogólnokształcące. Szkoły zawodowe kształcą na potrzeby edukacji (Kolegium Nauczycielskie), administracji, budownictwa, gastronomii, usług motoryzacyjnych. Obserwuje się tendencje do otwierania innowacyjnych kierunków kształcenia, na przykład w zawodzie technik mechatronik.

Trzy szkoły znajdują się we wsiach, z których jedna jest siedzibą gminy, dwie są miejscowościami sołeckimi. Jedna ze wsi sołeckich liczy 1,3 tys. mieszkańców, leży niedaleko Krakowa, w powiecie wielickim, przy szlaku tranzytowym drogowym (autostrada i droga krajowa) i kolejowym. Dojazd do centrum Krakowa zabiera 15-30 min. W tej wsi większość mieszkańców utrzymuje się ze źródeł pozarolniczych, co wiąże się z zanikiem działalności rolniczej. Po ukończeniu gimnazjum młodzież dojeżdża do szkół w Krakowie, Wieliczce i Bochni. Większość uczy się w liceach ogólnokształcących. $\mathrm{Z}$ wywiadu przeprowadzonego z nauczycielem wynika, że pozostali uczniowie przy wyborze zawodu kierują się ofertą kształcenia szkół najbliższych miejscu zamieszkania (Wieliczka, Bochnia), o czym decydują względy ekonomiczne. Chodzi o wysokie koszty dojazdu do szkół odległych od miejsca zamieszkania oraz o zbyt duże koszty związane z zamieszkaniem ucznia poza domem rodzinnym, takie jak opłata za internat. W tym wypadku wybrany kierunek kształcenia jest zazwyczaj przypadkowy i nie wiąże się ani z wizją przyszłej kariery zawodowej, ani z potrzebami lokalnego rynku pracy. Skazuje to młodych ludzi na bezrobocie, które w tej wsi jest często niejako dziedziczone po rodzicach. Sytuację gospodarczą w powiecie wielickim określa między innymi bezrobocie wynoszące $9,4 \%$. Chłonnym rynkiem pracy jest Kraków, lecz barierą dla młodzieży z tej wsi jest brak wysokich kwalifikacji zawodowych związany z nieporadnością przy wyborze zawodu.

Druga ze wsi sołeckich leży w powiecie lipnowskim, w województwie kujawsko-pomorskim. Najbliższej położonym miastem jest Lipno $(6 \mathrm{~km})$, a największym miastem w okolicy jest Włocławek $(15 \mathrm{~km})$. Jest to typowa wieś rolnicza, w której niemal wszystkie rodziny utrzymują się z pracy w rolnictwie, $w$ gospodarstwach średnich i dużych. Nieliczni utrzymują się z pracy najemnej w Lipnie i Włocławku. Sytuację gospodarczą w powiecie lipnowskim obrazuje między innymi bardzo wysoka stopa bezrobocia, wynosząca $23,1 \%$. Z uzyskanych informacji wynika, że zdecydowana większość absolwentów gimnazjum korzysta z oferty edukacyjnej szkół w Lipnie. Niewielka grupa uczniów kontynuuje naukę w szkołach we Włocławku. Jest to związane z wyższymi kosztami dojazdu do szkół w tym mieście. Uzyskano również informację, że niemała grupa absolwentów wiąże swoją przyszłość z pracą w rolnictwie. 
Trzecie wieś - gminna - znajduje się daleko od ważnych szlaków komunikacyjnych. Najbliższym miastem jest Wieluń, gdzie kontynuują naukę prawie wszyscy absolwenci miejscowego gimnazjum. Jest to wieś, w której dominującym źródłem utrzymania ludności jest praca w rolnictwie (gospodarstwa średnie i duże). Są również rodziny utrzymujące się z pracy poza rolnictwem, w miejscowych firmach, instytucjach, handlu oraz z pracy w pobliskim Wieluniu. Występują również mieszane źródła utrzymania (praca w rolnictwie i poza rolnictwem). Sytuację gospodarczą obrazuje między innymi stopa bezrobocia, wynosząca w powiecie wieluńskim 11\%. Problemem jest oferta kształcenia $\mathrm{w}$ tradycyjnych zawodach, na które nie ma zapotrzebowania na lokalnym rynku pracy. Z informacji uzyskanych od nauczyciela miejscowego gimnazjum wynika, że absolwenci po uzyskaniu zawodu, szczególnie na wyższym poziomie kształcenia, migrują do miast. Dlatego w tej wsi występuje niekorzystne zjawisko odpływu ludzi młodych, dobrze wykształconych oraz postępuje proces starzenia się ludności.

\section{Organizacyjne i dydaktyczne uwarunkowania ksztaltowania kompetencji biznesowych}

Nauczanie wiedzy o społeczeństwie odbywa się na solidnym fundamencie, który stanowią: nowa podstawa programowa i program nauczania, dobrze przygotowani nauczyciele, z dużym doświadczeniem zawodowym oraz szkoły dobrze wyposażone w sprzęt komputerowy i multimedialny.

Nowa podstawa programowa oraz programy nauczania wniosły innowacyjne treści wynikające ze zmieniającej się rzeczywistości politycznej, społecznej i gospodarczej. Zachęcają one nauczycieli do stosowania metod aktywizujących, spośród których najpopularniejszą jest metoda projektów (por. Tracz, Rachwał 2008). Programy nauczania realizują nauczyciele dobrze przygotowani do zawodu, z długoletnim stażem pracy.

Odczuwalnym mankamentem systemu kształcenia nauczycieli przedmiotu wiedza o społeczeństwie jest brak kierunku studiów zbieżnego z tym przedmiotem. Wiedzy o społeczeństwie nauczają absolwenci studiów magisterskich w zakresie historii oraz geografii. Uprawnienia do nauczania tego przedmiotu uzyskali po ukończeniu studiów podyplomowych. Zdaniem nauczycieli biorących udział w wywiadzie, taki system przygotowania zawodowego nie zapewnił im minimum niezbędnej wiedzy w szczególności do realizacji tematów z zakresu prowadzenia działalności gospodarczej oraz kształcenia przedzawodowego (por. wcześniejsze badania Tracz, Rachwał 2007). Żaden z nauczycieli nie prowadził własnej działalności gospodarczej, co niewątpliwie byłoby pomocne w pracy dydaktycznej.

Nauczyciele uzupełniają wiedzę poprzez samokształcenie, w którym wykorzystują fachowe publikacje, programy i audycje ekonomiczne w radiu i telewizji oraz serwisy internetowe. Korzystają też z kursów i szkoleń organizowanych na przykład przez Centrum Edukacji Obywatelskiej, Małopolski Urząd Wojewódzki oraz Fundację Rozwoju Przedsiębiorczości w Łodzi. Odczuwają jednak brak form doskonalenia zawodowego (np. kursów, konferencji, szkoleń) ukierunkowanych na podnoszenie kwalifikacji w zakresie kształtowania kompetencji biznesowych w gimnazjum.

Podstawowym dokumentem, na podstawie którego realizowane są treści kształcenia, jest podstawa programowa. Nowa podstawa programowa przedmiotu wiedza o społeczeństwie w części dotyczącej kształtowania kompetencji biznesowych jest przez nauczycieli wysoko oceniana. Ocena taka wynika z nacisku, jaki położono w podstawie programowej na:

- kształtowanie u ucznia odwagi podejmowania ryzyka w przedsiębiorczości i uświadomienie uczniowi trudu prowadzenia własnej firmy oraz trudu wejścia na rynek, ujawnienie plusów i minusów bycia szefem firmy,

- wyposażenie ucznia w wiedzę o podstawowych prawidłowościach, regułach i instytucjach życia publicznego, kształtowanie jego postawy obywatelskiej, 
- wzbudzanie zainteresowania życiem publicznym oraz poszukiwaniem, przetwarzaniem i porządkowaniem informacji,

- uczenie współpracy w grupie w rzeczywistym działaniu społecznym, uczenie języka politycznego w zakresie umiejętności prowadzenia debat, dyskusji i zebrań,

- motywowanie uczniów do samokształcenia i prowadzenia działalności biznesowej poprzez kształtowanie umiejętności funkcjonowania w społeczeństwie.

Nauczyciele ocenili pozytywnie nową podstawę programową, jednocześnie wskazali też zmiany w jej zapisach, które ich zdaniem wpłynęłyby jeszcze korzystniej na kształtowanie kompetencji biznesowych w gimnazjum. Są to:

- usunięcie treści związanych z predyspozycjami zawodowymi i wyborem przyszłego zawodu, gdyż na tym etapie kształcenia są one przedwczesne,

- aktualizowanie treści z zakresu wiedzy ekonomicznej rynku pracy,

- uwzględnianie w większym stopniu treści związanych z nowymi zawodami, na które jest lub będzie zapotrzebowanie na rynku pracy,

- wprowadzenie treści związanych z samorządem lokalnym i jego rolą w kreowaniu lokalnego rynku pracy w miejsce treści o funkcjonowaniu państwa,

- rozbudowanie modułów: Kształcenie postaw obywatelskich, Instytucje państwa demokratycznego,

- włączenie tematów o bieżących wydarzeniach społecznych, gospodarczych i politycznych w Polsce, UE i na świecie,

- rozszerzenie bloku tematów związanych z kształcenie przedzawodowym.

W powyższym zestawieniu propozycji zmian są takie, które wzajemnie się wykluczają, co świadczy o subiektywnej ocenie zapisów podstawy programowej, dokonywanej przez pryzmat sytuacji we własnej szkole lub regionie. Zwraca uwagę akcentowanie treści związanych z samorządem lokalnym. Prawdopodobnie wynika to z faktu, iż badania prowadzono bezpośrednio przed i po wyborach samorządowych w 2009 roku. Fakt ten można również zinterpretować inaczej - jako dążenie do powiązania kształtowania postaw biznesowych z realiami ekonomicznymi w wymiarach lokalnym i ponadlokalnym (poprzez włącznie treści związanych z bieżącymi wydarzeniami w Polsce, Unii Europejskiej i na świecie). Bez wątpienia, wprowadzenie tych postulatów korzystnie wpłynie na efekty kształcenia przedzawodowego.

Podstawa programowa była realizowana w badanych szkołach poprzez następujące programy nauczania:

- Pacewicz A., Merta T., Żmijewska-Kwiręg S., 2010, Kształcenie obywatelskie w szkole samorzadowej, Centrum Edukacji Obywatelskiej, Civitas, Warszawa,

- Wesołowska-Starnawska M., Starnawski W., 2009, Program nauczania wiedzy o społeczeństwie w gimnazjum - Bliżej Świata, EREMIS, Warszawa (dwóch nauczycieli),

- Kowalewska T., 2010, „Dziś i jutro”- program nauczania ogólnego wiedzy o społeczeństwie w klasach I-III gimnazjum, wydawnictwo Nowa Era, Warszawa (dwóch nauczycieli),

- Dobrzycka E., Makara K., 2009, Wiedza o społeczeństwie - program nauczania dla gimnazjum, Wyd. Pedagogiczne Operon, Gdynia,

- Kosińska E., Zamorska U., 2008, Wychowanie obywatelskie-wiedza o społeczeństwie dla klas I-III gimnazjum, Wyd. i Hurtownia Rubikon, Kraków.

Wszystkie programy realizowane w klasach I i II są zgodne z nową podstawą programową. Nie wymagają one szczególnych warunków, mogą być realizowane w istniejących warunkach funkcjonowania szkół. Niemniej jednak niektóre tematy powinny być (i są) wprowadzane w pracowniach komputerowych lub multimedialnych z dostępem do Internetu lub z wykorzystaniem zestawów multimedialnych (komputer i projektor multimedialny). 
Siatka godzin teoretycznie wystarcza na pełną realizację programów nauczania. Wiedza o społeczeństwie nauczana jest przez dwa lata nauki, najczęściej w klasie I i II po jednej godzinie tygodniowo. W prywatnym gimnazjum, w którym można było zwiększyć liczbę godzin, program nauczania realizowany jest również w klasie III, czyli w trzyletnim cyklu nauczania po jednej godzinie tygodniowo. W jednym gimnazjum przedmiot nauczany jest w klasie II i III.

$\mathrm{Na}$ takie rozwiązania pozwala elastyczność programów nauczania w zakresie ich czasowej realizacji. Zdaniem nauczycieli, jest to najlepszy sposób, gdyż przedmiot powinien być nauczany w klasach I-III, tak, aby nie było przerwy pomiędzy końcem cyklu nauczania a egzaminem gimnazjalnym. Niektóre programy nauczania przewidują kilkanaście godzin do dyspozycji nauczyciela. Daje to możliwość rozszerzania zakresu tematycznego przedmiotu oraz dostosowania czasu realizacji niektórych tematów do zainteresowań i zdolności uczniów.

Mocnymi stronami programów nauczania wskazanymi przez nauczycieli są:

- zgodność z podstawą programową,

- możliwość realizacji w każdych warunkach szkolnych,

- elastyczność czasu realizacji (Pacewicz i inni 2010, Kowalewska 2008),

- dodatkowe godziny do dyspozycji nauczyciela (Kowalewska 2008).

Słabe strony programów zdaniem nauczycieli to:

- napięty czas realizacji;

- nieuwzględnienie czasu potrzebnego na stasowanie metod aktywizujących,

- brak tematów związanych z bieżącymi wydarzeniami społecznymi, gospodarczymi i politycznymi w kraju, UE.

Po części ocena programów nauczania dokonana przez nauczycieli wynika z oceny podstawy programowej. Dotyczy to głównie konieczności powiązania kształtowania kompetencji biznesowych, zwłaszcza w zakresie kompetencji wyposażenia w wiedzę ekonomiczną, z realiami sytuacji społeczno-gospodarczej w skalach lokalnej, krajowej, regionalnej, a nawet globalnej. Brak powiązania edukacji z rzeczywistością to słaba strona programów nauczania.

Nauczyciele zwrócili również uwagę na napięty czas realizacji programów nauczania - nie zawsze realna liczba godzin lekcyjnych zgadza się z przewidzianą w programie nauczania. Wynika to głównie $\mathrm{z}$ realizacji przedmiotu w drugim semestrze, gdy na przykład z powodu egzaminu gimnazjalnego lub wycieczek zajęcia przewidziane w planie lekcji nie odbywają się. Ponadto przy ścisłej korelacji liczby tematów z liczbą godzin (jeden temat na jedną jednostkę lekcyjną) brakuje czasu na stosowanie w nauczaniu metod aktywizujących, które wydłużają czas potrzebny na zrealizowanie tematu lekcji.

Pomimo tego mankamentu nauczyciele chętnie stosują metody aktywizujące, takie jak:

- metoda projektów,

- praca z materiałem źródłowym (druki i formularze niezbędne do załatwienia spraw urzędowych, np. uzyskania dowodu osobistego),

- dyskusja,

- debata,

- dyskusja piramidowa (kula śnieżna),

- burza mózgów,

- metaplan,

- drzewo decyzyjne,

- analiza SWOT,

- gry dydaktyczne: drama, symulacja, krzyżówki, łamigłówki oraz rebusy. 
Stosowanie metod aktywizujących podnosi efektywność kształtowania wszystkich czterech kompetencji: biznesowych, wyposażenia w wiedzę ekonomiczną, osobistych i społecznych. Jako najlepszą wskazywano metodę projektów. Zdaniem jednego z nauczycieli, metoda ta daje uczniowi wiedzę i kształtuje umiejętności związane z przedmiotem projektu, rozwija zainteresowania, zmusza ucznia do poszukiwania sposobów badania i rozwiązania problemu, uczy organizacji własnej pracy, współpracy z innymi, pracy w grupie. Uczeń wytrwale i w przemyślany sposób dąży do realizacji zamierzonego celu, przygotowuje i przeprowadza publiczną prezentację projektu.

W kształtowaniu kompetencji osobistych efektywne są metody personalizacji, kierujące uwagę nauczyciela na każdego ucznia, odwołujące się do jego doświadczeń i pokazujące uczniowi, że jest uczestnikiem życia społecznego, w którym odgrywa wiele ról. Ważne są również metody socjalizacji, odwołujące się do wiedzy i doświadczeń uczniów, które wynieśli z innych źródeł (np. od rodziców, dziadków, rówieśników), a także pozyskali z informacji zdobytych w Internecie czy innych mediach.

Zdaniem nauczycieli, w świetle podstawy programowej oraz programów nauczania ogólnymi celami wiedzy o społeczeństwie w zakresie edukacji z przedsiębiorczości, edukacji ekonomicznej i przedzawodowej oraz celami kształcenia kompetencji biznesowych są:

- korzystanie z informacji z zakresu spraw społecznych, gospodarczych i polityki, rozumienie tej informacji i korzystanie z niej przy realizacji różnych zadań i projektów,

- przekazywanie uczniom wiedzy ekonomicznej,

- kształtowanie rozumienia zasad gospodarki rynkowej (rozumienie zasad gospodarki rynkowej, procesów gospodarczych, zasad racjonalnego gospodarowania, rynku, giełdy papierów wartościowych, papierów wartościowych, rynku pracy ze szczególnym uwzględnieniem bezrobocia i sposobów wychodzenia z niego).

W ocenie nauczycieli mocnymi i słabymi stronami kształtowania kompetencji biznesowych $\mathrm{w}$ świetle programów nauczania są elementy wymienione w tabeli 1 .

Tab. 1. Mocne i słabe strony kształcenia biznesowego w świetle programów nauczania

\begin{tabular}{|c|l|}
\hline \multicolumn{1}{|c|}{ Mocne strony } & \multicolumn{1}{c|}{ Slabe strony } \\
\hline 1. Prawidłowy dobór treści kształcenia i tematów & $\begin{array}{l}\text { Zbyt wczesny etap kształcenia. Niektóre treści, } \\
\text { np. kształcenie biznesowe i przedzawodowe, } \\
\text { powinny wystąpić na kolejnym, wyższym etapie } \\
\text { kształcenia }\end{array}$ \\
\hline $\begin{array}{l}\text { 2. Uniwersalizm wartości zawartych w programie } \\
\text { nauczania }\end{array}$ & Napięty czas realizacji programu nauczania \\
\hline $\begin{array}{l}\text { 3. Właściwy dobór proporcji tematów w zakresie } \\
\text { czterech kompetencji }\end{array}$ & Brak czasu na stosowanie metod aktywizujących \\
\hline $\begin{array}{l}\text { 4. Zgodność z podstawą nauczania } \\
\text { godzin na realizację programu nauczania }\end{array}$ & $\begin{array}{l}\text { Brak tematów związanych z bieżącymi wydarze- } \\
\text { nia społecznymi, gospodarczymi i politycznymi } \\
\text { w kraju, UE i na świecie }\end{array}$ \\
\hline $\begin{array}{c}\text { 5. W zakresie podstawowym wystarczajaca liczba } \\
\text { gealizacja programu nauczania w I i II klasie, } \\
\text { co powoduje przerwę pomiędzy końcem nauki } \\
\text { a egzaminem gimnazjalnym }\end{array}$ \\
\hline $\begin{array}{l}\text { 6. Program nie wymaga szczególnych warunków } \\
\text { do realizacji }\end{array}$ & $\begin{array}{l}\text { Zbyt mało tematów z zakresu kształcenia } \\
\text { przedzawodowego }\end{array}$ \\
\hline
\end{tabular}

Źródło: opracowanie własne. 
Poprzez kilkakrotne wskazanie na rozumienie zasad gospodarki rynkowej jako głównego celu przedmiotu zaakcentowano ważność tego właśnie celu pośród innych celów wiedzy o społeczeństwie w zakresie kształtowania kompetencji biznesowych. Uczeń powinien zrozumieć istotę zachodzących procesów gospodarczych, znać i wdrażać zasady racjonalnego gospodarowania w życiu codziennym (np. poprzez planowanie własnych wydatków). Uczeń powinien umieć analizować kierunki dalszej nauki i kariery zawodowej w kontekście własnych predyspozycji.

Aby te cele osiągnąć, nauczyciele ukierunkowują kształtowanie kompetencji biznesowych na:

- kształtowanie aktywnych postaw w zakresie pozyskiwania i wykorzystywania informacji ekonomicznej, jej oceny i wyboru odpowiednich treści,

- kształtowanie zachowań w odniesieniu do bieżących problemów ekonomicznych,

- rozumienie rzeczywistości ekonomicznej poprzez dostrzeganie i właściwą interpretację zachodzących w niej procesów i zjawisk, umiejętność odnalezienia się w niej,

- poznanie podstawowych zasad ekonomicznych,

- poznanie zasad funkcjonowania gospodarki rynkowej,

- umiejętność odnalezienia się na rynku pracy, kształtowanie postaw, których od pracownika wymaga pracodawca,

- umiejętność podejmowania decyzji,

- znajomość zasad funkcjonowania przedsiębiorstwa,

- ocenę własnych możliwości w zakresie kierunku dalszego kształcenia i wyboru zawodu.

Kształtowanie kompetencji biznesowych w zakresie kompetencji osobistych i wyposażenia w wiedzę ekonomiczną wspomagają wycieczki do firm oraz instytucji, takich jak: giełda papierów wartościowych, Sejm i Senat. Ważnym elementem procesu kształcenia kompetencji biznesowych związanych bezpośrednio z przygotowaniem do prowadzenia działalności gospodarczej jest transformacja doświadczeń biznesowych na grunt szkolny przez uczniów, których rodzice prowadzą firmy.

Zdaniem nauczycieli, najważniejszymi kompetencjami w świetle podstawy programowej wiedzy o społeczeństwie są (wg częstości wskazań):

- kompetencje społeczne,

- kompetencje osobiste i kompetencje biznesowe,

- kompetencje w zakresie wyposażenia w wiedzę ekonomiczną.

Nieco inaczej przedstawia się hierarchia kompetencji kształcenia biznesowego postrzegana przez pryzmat programów nauczania:

- kompetencje w zakresie wyposażenia uczniów w wiedzę ekonomiczną,

- kompetencje społeczne,

- kompetencje osobiste,

- kompetencje biznesowe.

W celu podniesienia efektywności kształcenia biznesowego nauczyciele włączają uczniów w przedsięwzięcia ponadprogramowe. Tym sposobem kształcenie biznesowe wychodzi poza ramy szkolne na grunt lokalnego środowiska. Przykładami takich działań są:

- udział uczniów w programie „Azymut” finansowanym przez UE w ramach projektu Kapitał Ludzki,

- włączenie uczniów do programu „Powalczmy o przyszłość” finansowanego przez UE w ramach programu Aktywności Lokalnej z funduszu Kapitał Ludzki. W zajęciach w Gminnym Ośrodku Pomocy Społecznej wzięło udział 11 uczniów. Zajęcia prowadzili: doradca zawodowy, pedagog i psycholog. Celem zajęć było nabycie wiedzy z zakresu kompetencji społecznych i aktywności zawodowej. Uczniowie poznali swoje mocne i słabe strony, co pozwoliło na doprecyzowanie i wybór kierunku dalszej edukacji. 
Na podstawie własnych doświadczeń nauczyciele wskazali zmiany, które chcieliby wprowadzić w obowiązującej podstawie programowej przedmiotu wiedza o społeczeństwie $\mathrm{i}-\mathrm{w}$ konsekwencji - w programach nauczania tego przedmiotu. Miałyby one polegać na:

- zmianach zakresu wiedzy ekonomicznej i o rynku pracy nawiązującej do dynamiki gospodarki rynkowej,

- uwzględnieniu wiedzy o nowych zawodach, na które jest lub będzie zapotrzebowanie na rynku pracy,

- wprowadzeniu tematów związanych z samorządem lokalnym (struktura, zadania, rola w społeczności lokalnej) w miejsce tematów o funkcjonowaniu państwa,

- rozbudowanie modułów Kształcenie postaw obywatelskich i Instytucje państwa demokratycznego,

- włączeniu tematów o bieżących wydarzeniach społecznych, gospodarczych i politycznych w Polsce, UE i na świecie,

- dodaniu treści ukazujących plusy i minusy przynależności Polski do UE,

- ograniczeniu treści związanych z predyspozycjami zawodowymi i wyborem przyszłego zawodu.

Zaskakująca jest ostatnia propozycja zmiany w podstawie programowej. Wynika ona ze specyfiki postaw uczniów w jednym z gimnazjów, w którym 99\% absolwentów kontynuuje naukę w liceach ogólnokształcących. W związku z tym wybór zawodu i związanego z tym kierunku kształcenia przesuwa się w ich przypadku na dalszy etap kształcenia. Inni nauczyciele, nie postulując tak radykalnych zmian w podstawie programowej, sugerowali, że treści związane z kształceniem przedzawodowym wprowadzane są zbyt wcześnie.

\section{Ocena kształcenia przedzawodowego w kontekście kształtowania kompetencji biznesowych w świetle wypowiedzi nauczycieli}

Tylko dwóch badanych nauczycieli uważa, że wiedza o społeczeństwie pomaga uczniom gimnazjów wybrać dalszą drogę kształcenia oraz przyszły zawód i jest pomocna w poszukiwaniu pracy. Wśród pozostałych pedagogów przeważa przekonanie, że przedmiot ten nie pomaga w wyborze dalszej drogi kształcenia, a wybór przyszłego zawodu determinują czynniki zewnętrzne:

- chęć dalszego kształcenia w liceach ogólnokształcących, co wynika z predyspozycji i aspiracji uczniów uzyskania wyższego wykształcenia. Z takim nastawieniem rozpoczynają naukę w gimnazjum i to powoduje, że odsuwają wybór zawodu i związanego z tym kierunku dalszego kształcenia na etap edukacji ponadgimnazjalnej;

- wpływ rodziców. Dzieci wybierają zawód związany z działalnością biznesową rodziców, ponieważ wiążą swoją przyszłość z kontynuacją ich działalności gospodarczej, czyli, jak można powiedzieć, dziedziczą zawód po rodzicach. Taka tendencja została zauważona w Krakowie i jednej ze szkół wiejskich. W pierwszym przypadku związane jest to z sukcesją firm rodzinnych, w drugim - z wyborem zawodu rolnika i kształceniem w szkołach rolniczych, aby prowadzić w przyszłości gospodarstwa przejęte od rodziców;

- względy ekonomiczne (koszty dojazdu do szkoły lub zamieszkania poza domem rodzinnym w innej miejscowości - mieście). Uczniowie wybierają szkoły położone najbliżej miejsca zamieszkania. Wybór zawodu jest często przypadkowy, gdyż wynika z oferty edukacyjnej tych szkół. Uczniowie ci nie wiążą swej przyszłości z wybranym zawodem, uczą się, mając świadomość, że i tak w przyszłości będą wykonywać pracę niezwiązaną z wybranym kierunkiem kształcenia zawodowego;

- wpływ koleżanek i kolegów. Kierunek kształcenia zawodowego na etapie ponadgimnazjalnym nie wynika ze świadomego wyboru własnej drogi kształcenia, która w perspektywie zapewniłaby solidny grunt na rynku pracy. 
Nauczyciele obserwują aktywne i bierne podejście uczniów do wyboru przyszłego zawodu czy też dalszej drogi kształcenia. Pasywna postawa uczniów w tym zakresie powoduje, że uzyskują oni zawody, na które nie ma zapotrzebowania. W konsekwencji uczniowie wpadają w bezrobocie, z którego trudno im wyjść. Zdarza się, że dziedziczą je po rodzicach, a wraz z nim - biedę.

Edukacja przedzawodowa jest najsłabszym ogniwem w kształceniu kompetencji biznesowych w ramach przedmiotu wiedza o społeczeństwie, szczególnie w gimnazjach wiejskich. W dwóch szkołach uczniowie nie uzyskują wiedzy o przyszłych zawodach, w dwóch prezentowane są zawody występujące w najbliższej okolicy, a tylko w jednej uczniowie mogą liczyć na pozyskanie koniecznej wiedzy w tym zakresie.

Zdaniem nauczycieli, słabość kształcenia przedzawodowego na poziomie gimnazjalnym wynika z:

- nazbyt wczesnego etapu edukacji, na którym wprowadza się kształcenie przedzawodowe,

- silnego wpływu czynników zewnętrznych powodujących brak zainteresowania uczniów kształceniem przedzawodowym.

Analiza wypowiedzi nauczycieli wskazuje także inne przyczyny. Są to:

- sztywne zapisy podstawy programowej, ograniczające swobodę realizacji kształcenia przed-zawodowego w zakresie doboru treści i czasu przeznaczonego na to kształcenie,

- brak powiązania kształcenia przedzawodowego na poziomie gimnazjalnym z pracodawcami lub organizacjami pracodawców (jest to przedmiot badań dalszych etapów realizacji projektu FIFOBI),

- brak korelacji zakresu edukacji przedzawodowej z sytuacją na rynku pracy.

Moduł kształcenia przedzawodowego w podstawie programowej powinien być elastyczny. Podstawa programowa nie powinna krępować nauczyciela w zakresie doboru tematów kształcenia przedzawodowego, które może włączyć do w programu nauczania. Tematy te muszą być realizowane w określonym wymiarze czasowym, ale bez wyznaczonego terminu ich realizacji. To zapewni aktualność tematyki zajęć oraz umożliwi powiązanie kształcenia przedzawodowego z dynamiką rynku pracy.

Rozmowy z nauczycielami skłaniają do wniosku, że kształcenie przedzawodowe na poziomie gimnazjalnym nie znajduje się w sferze zainteresowań pracodawców. Żaden z nauczycieli nie spotkał się z jakąkolwiek inicjatywą włączenia się pracodawców lub ich organizacji w tok kształcenia przedzawodowego. W szkołach nie odbywają się spotkania młodzieży z przedstawicielami lokalnego biznesu. Wizyty młodzieży w firmach też są rzadkością, a jeżeli już się odbywają, to są ograniczone do prezentacji technicznych aspektów procesu produkcyjnego. Pomija się przy tym zasady organizacji i funkcjonowania firmy.

Nauczyciele gimnazjów nie wskazali przykładów angażowania się w realizację edukacji przedzawodowej lub prowadzenia badań predyspozycji zawodowych pracowników urzędów pracy i doradców zawodowych.

\section{Wnioski}

Ogólna ocena kształcenia biznesowego w ramach przedmiotu wiedza o społeczeństwie jest dobra. Oceny edukacji w zakresie poszczególnych kompetencji są zróżnicowane. Najwyżej przez nauczycieli ocenione zostały efekty kształcenia w zakresie wyposażenia uczniów w wiedzę ekonomiczną. Słabo wypada kształcenie w zakresie kompetencji biznesowych w wąskim rozumieniu, a najgorzej przedstawia się edukacja przedzawodowa. Zdaniem nauczycieli, pożądanymi kierunkami zmian w kształceniu biznesowym na poziomie gimnazjalnym są:

- połączenie wiedzy przekazywanej na lekcji z życiem,

- włączenie projektów ekonomicznych opracowanych przez Centrum Kształcenia Obywatelskiego oraz inne instytucje i organizacje, 
- przesunięcie edukacji biznesowej na wcześniejszy termin - zgodnie z programem, kształcenie to występuje w końcu roku szkolnego, co z uwagi na przedwakacyjny termin nie jest korzystne $\mathrm{z}$ uwagi na efekty tego kształcenia.

W nawiązaniu do pierwszego kierunku oczekiwanych zmian dodać należy konieczność włączenia do kształcenia przedzawodowego kontaktów z pracodawcami oraz przedstawicielami instytucji państwowych kreujących politykę prozawodową. Z przeprowadzonych badań wynika, że edukacja biznesowa na poziomie gimnazjalnym znajduje się poza sferą zainteresowań wymienionych grup realnie wpływających na lokalny i krajowy rynek pracy.

Kształcenie biznesowe, szczególnie w zakresie edukacji przedzawodowej na gimnazjalnym etapie edukacji jest niezwykle ważne, gdyż ten etap decyduje o karierze zawodowej młodzieży. Dotyczy to również uczniów, którzy wybierają dalszą naukę w liceach ogólnokształcących. Taki wybór to pozorne odłożenie decyzji o wyborze drogi kształcenia i wyborze zawodu „na później”. Kandydat na ucznia liceum ogólnokształcącego musi już na wstępie wybrać określoną ścieżkę kształcenia, co przekłada się na wybór profilu klasy, a później - zakres egzaminu maturalnego. Przede wszystkim dotyczy to młodzieży kontynuującej naukę w szkołach zawodowych, która bardzo często po szkole trafia bezpośrednio na rynek pracy. Wskazywano na ten problem szerzej we wcześniejszej pracy poświęconej zmianom programowym w edukacji w zakresie przedsiębiorczości (Rachwał 2009).

W gimnazjalnym kształceniu przedzawodowym konieczne jest odejście od teorii na rzecz realiów, poprzez likwidację bariery dzielącej edukację i decydentów kreujących procesy ekonomiczne oraz rynek pracy przede wszystkim w zakresie lokalnym, jak również krajowym. Wymaga to pewnych zmian w podstawie programowej, które przełożyłyby się na kreatywne zachowanie nauczyciela i uczniów, czyli osób kluczowych w procesie kształcenia biznesowego.

Pozytywnym przykładem zmian w tym kierunku jest transfer doświadczeń biznesowych za pośrednictwem uczniów, których rodzice prowadzą firmy, do procesu kształtowania kompetencji biznesowych na lekcjach wiedzy o społeczeństwie w jednym z prywatnych gimnazjów w Krakowie.

\section{Literatura}

1. Berger S., Pilz M., 2010, Fit for business: Developing business competencies in school (FIFOBI). Vorstellung eines europäischen Vergleichsprojekts zur Optimierung der ökonomischen Bildung und Förderung des Unternehmertums an allgemeinbildenden Schulen [w:] „Wirtschaft und Erziehung”, 62(3), s. 70-72.

2. Borowiec M., Rachwał T., 2011, Ksztaltowanie postaw przedsiębiorczych na lekcjach geografii wyzwaniem edukacyjnym w procesach globalizacji [w:] Przedsiębiorczość w warunkach globalizacji, Z. Zioło, T. Rachwał (red.), „Przedsiębiorczość - Edukacja”, nr 7, wydawnictwo Nowa Era, Zakład Przedsiębiorczości i Gospodarki Przestrzennej Instytutu Geografii Uniwersytetu Pedagogicznego im. Komisji Edukacji Narodowej w Krakowie, Warszawa - Kraków, s. 321-332.

3. Kurek S., Rachwał T., 2009, Założenia i wstępne wyniki europejskiego projektu badawczego FIFOBI w zakresie kształtowania kompetencji uczniów gimnazjum do prowadzenia działalności gospodarczej [w:] Przedsiębiorczość w warunkach integracji europejskiej, Z. Zioło, T. Rachwał (red.), „Przedsiębiorczość - Edukacja”, nr 6, wydawnictwo Nowa Era, Zakład Przedsiębiorczości i Gospodarki Przestrzennej Instytutu Geografii Uniwersytetu Pedagogicznego im. Komisji Edukacji Narodowej w Krakowie, Warszawa - Kraków, s. 472-485. 
4. Kurek S., Rachwał T., 2010, The Role of Business Education in the Development of Entrepreneurship in the Member States of the European Union, "Europa XXI", vol. 19, PAN, Warszawa, pp. 127-142.

5. Kurek S., Rachwał T., 2011, Development of entrepreneurship in ageing populations of The European Union, "Procedia. Social and Behavioral Science", vol. 19 (2011), s. 397-405.

6. Micek G., 2008, Rozwój usług informatycznych w Polsce w ujęciu przestrzennym [w:] Przemiany w sferze ustug w Polsce, J. Dominiak (red.), Wydawnictwo Naukowe Bogucki, Poznań, s. 93-110.

7. Micek G., Działek J., Górecki J., 2011, The Disclosure and Realities of Offshore Business Services to Kraków, "European Planning Studies", 19(9), s. 1651-1668.

8. Naudé W., 2008, Entrepreneurship in Economic Development, "Research Paper", No. 2008/20, World Institute for Development Economics Research, s. 1-47.

9. Osuch W., 2011, Kompetencje w zakresie komunikacji interpersonalnej w dobie postepujacych procesów globalizacji [w:] Przedsiębiorczość w warunkach globalizacji, Z. Zioło, T. Rachwał (red.), „Przedsiębiorczość - Edukacja”, nr 7, wydawnictwo Nowa Era, Zakład Przedsiębiorczości i Gospodarki Przestrzennej Instytutu Geografii Uniwersytetu Pedagogicznego im. Komisji Edukacji Narodowej w Krakowie, Warszawa - Kraków, s. 333-346.

10. Rachwał T., 2006, Restrukturyzacja przedsiębiorstw przemysłowych Krakowskiego Obszaru Metropolitalnego [w:] Rzeszowski i Krakowski Obszar Metropolitalny, Z. Makieła, R. Fedan (red.), Wydawnictwo Krakowskiej Szkoły Wyższej, Kraków, s. 225-240.

11. Rachwał T., 2009, Ocena projektu zmian podstawy programowej podstaw przedsiębiorczości (przedstawionej przez MEN w 2008 r. w ramach reformy systemu edukacji) [w:] Rola przedsiębiorczości $w$ kształtowaniu społeczeństwa informacyjnego, Z. Zioło, T. Rachwał (red.), „Przedsiębiorczość - Edukacja”, nr 5, wydawnictwo Nowa Era, Zakład Przedsiębiorczości i Gospodarki Przestrzennej Instytutu Geografii Uniwersytetu Pedagogicznego im. Komisji Edukacji Narodowej w Krakowie, Warszawa - Kraków, s. 349-372.

12. Rachwał T., 2010, Chapter 9. Entrepreneurship Education as a Growth Stimulus for Family Firms [w:] Exploring the Dynamics of Entrepreneurship, A. Surdej, K. Wach (red.), A. Marszałek Publishing House, Toruń, s. 139-156.

13. Tracz M., Rachwał T., 2007, Przedmiot podstawy przedsiębiorczości-założenia realizacji a przygotowanie nauczycieli [w:] Rola przedsiębiorczości w aktywizacji gospodarczej, Z. Zioło, T. Rachwał (red.), „Przedsiębiorczość - Edukacja”, nr 3, wydawnictwo Nowa Era, Zakład Przedsiębiorczości i Gospodarki Przestrzennej Akademii Pedagogicznej im. Komisji Edukacji Narodowej w Krakowie, Warszawa - Kraków, s. 286-296.

14. Tracz M., Rachwał T., 2008, Metody nauczania i środki dydaktyczne stosowane przez nauczycieli podstaw przedsiębiorczości wyniki badań [w:] Rola przedsiębiorczości w gospodarce opartej na wiedzy, Z. Zioło, T. Rachwał (red.), „Przedsiębiorczość - Edukacja”, nr 4, wydawnictwo Nowa Era, Zakład Przedsiębiorczości i Gospodarki Przestrzennej Instytutu Geografii Uniwersytetu Pedagogicznego im. Komisji Edukacji Narodowej w Krakowie, Warszawa - Kraków, s. 325-330.

15. Wach K., 2007, Ksztaltowanie postaw przedsiębiorczych w programach nauczania. Stan obecny i proponowane kierunki zmian [w:] Ksztattowanie postaw przedsiębiorczych a edukacja ekonomicz$n a$, P. Wachowiak, M. Dąbrowski, B. Majewski (red.), Fundacja Promocji i Akredytacji Kierunków Ekonomicznych, Warszawa, s. 120-127.

16. Zioło Z., 2006, Rola przedsiębiorczości w podnoszeniu konkurencyjności społeczeństwa i gospodarki [w:] Rola przedsiębiorczości w podnoszeniu konkurencyjności społeczeństwa i gospodarki, Z. Zioło, T. Rachwał (red.), „Przedsiębiorczość - Edukacja”, nr 2, wydawnictwo Nowa Era, Zakład Przedsiębiorczości i Gospodarki Przestrzennej Instytutu Geografii Akademii Pedagogicznej im. Komisji Edukacji Narodowej w Krakowie, Warszawa - Kraków, s. 10-17.

17. Zioło Z., 2007, Rola przedsiębiorczości w aktywizacji gospodarczej-zarys modelu [w:] Rola przedsiębiorczości w aktywizacji gospodarczej, Z. Zioło, T. Rachwał (red.), „Przedsiębiorczość - Edukacja”, nr 3, wydawnictwo Nowa Era, Zakład Przedsiębiorczości i Gospodarki Przestrzennej Akademii Pedagogicznej im. Komisji Edukacji Narodowej w Krakowie, Warszawa - Kraków, s. 10-17. 
18. Zioło Z., 2010, Problemy rozwoju przedsiębiorczości w warunkach integracji europejskiej [w:] Przedsiębiorczość w warunkach integracji europejskiej, Z. Zioło, T. Rachwał (red.), „Przedsiębiorczość - Edukacja”, nr 6, wydawnictwo Nowa Era, Zakład Przedsiębiorczości i Gospodarki Przestrzennej Instytutu Geografii Uniwersytetu Pedagogicznego im. Komisji Edukacji Narodowej w Krakowie, Warszawa - Kraków, s. 10-24.

19. Zioło Z., 2011, Rola przedsiębiorczości w warunkach nasilających się procesów globalizacji [w:] Przedsiębiorczość w warunkach globalizacji, Z. Zioło, T. Rachwał (red.), „Przedsiębiorczość - Edukacja”, nr 7, wydawnictwo Nowa Era, Zakład Przedsiębiorczości i Gospodarki Przestrzennej Instytutu Geografii Uniwersytetu Pedagogicznego im. Komisji Edukacji Narodowej w Krakowie, Warszawa-Kraków, s. 10-23.

\section{Developing business competencies of students of lower secondary schools according to teachers' opinions based on results of research conducted within EC project FIFOBI}

The paper contains an analysis of the research results conducted among teachers in the research project FIFOBI - "Fit for business: developing business competencies in school". The study consisted in interviews carried out with teachers of the citizenship subject in six lower secondary schools. The interviews were conducted in a specific situation connected with implementation a new Core Curriculum and new syllabuses for the subject. This paper presents teachers' opinions regarding: the Core Curriculum for the citizenship subject as well as implementation of chosen syllabuses in relation to business skills development, a ranking of four business competencies that make up the business skills in a broad sense (as economic, social, personal and business competencies related with running your own business) in the process of teaching the citizenship subject, proposals for changes in the Core Curriculum (syllabuses) in the business education, resulting from implementation of their chosen syllabuses, teaching methods, pre-vocational education, evaluation of the educational process and its outcomes across all four competencies.

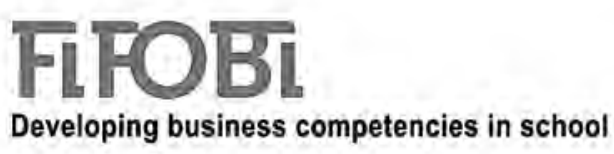

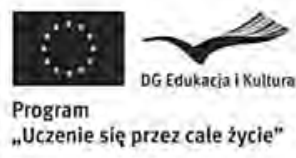

Publikacja powstała w ramach projektu „Fit for business: developing business competencies in school” (FIFOBI) realizowanego przy wsparciu finansowym Komisji Europejskiej w ramach Programu „Uczenie się przez całe życie" (Lifelong Learning Programme), numer projektu 143356-LLP-1-2008-1-DE-KA1-KA1SCR. Publikacja odzwierciedla jedynie stanowisko jej autorów i Komisja Europejska nie ponosi odpowiedzialności za umieszczoną w niej zawartość merytoryczną. 